\title{
Linking fine root and understory vegetation to channel erosion in forested hillslopes of southwestern China
}

\author{
Y. Li • H. Q. Yu • N. Zhou • G. Tian • J. Poesen • \\ Z. D. Zhang
}

Received: 6 October 2014 / Accepted: 4 December 2014 /Published online: 21 December 2014

(C) The Author(s) 2014. This article is published with open access at Springerlink.com

\begin{abstract}
Aims The forestland understory vegetation reduces concentrated overland flow through infiltration improvement by roots and raindrop interception by surface cover. However, little has been done to quantify the linkages between understory vegetation cover, roots, and channel erosion, and such information can help assessing the role of the reforestation in soil erosion control. In this study, we evaluated the relationships between channel density, root density,
\end{abstract}

Responsible editor: Alexia Stokes.

Y. Li $(\bowtie) \cdot$ H. Q. Yu $\cdot$ N. Zhou $\cdot$ Z. D. Zhang

Agricultural Clean Watershed Research Group, Institute of Environment and Sustainable Development in Agriculture, Chinese Academy of Agricultural Sciences (CAAS),

Beijing 100081, China

e-mail: liyong@caas.cn

G. Tian

Environmental Monitoring and Research Division, Monitoring and Research Department, Metropolitan Water Reclamation District of Greater Chicago,

Lue-Hing R\&D Complex, 6001W. Pershing Road, Cicero, IL 60804, USA

G. Tian

Department of Civil, Architectural and Environmental Engineering, Illinois Institute of Technology,

3201 South Dearborn Street, Chicago, IL 60616, USA

J. Poesen

Physical and Regional Geography Research Unit, Catholic University Leuven,

Redingenstraat 16, 3000 Leuven, Belgium and vegetation cover in forested hillslopes of southwestern China.

Methods Twelve locations (four slopes and three positions) of forested hillslopes with a wide range of understory degradation due to litterfall extraction and livestock grazing were selected for the study. Channel density as a measure of rill and (small) gully erosion, root density of different diameter classes, and vegetation cover of all types were determined using field measuring, soil coring and the line transect method, respectively. Soil loss rates were estimated using the caesium-137 $\left({ }^{137} \mathrm{Cs}\right)$ technique.

Results Rills (depth $<0.3 \mathrm{~m}$ ) with a width of $0.05-0.1 \mathrm{~m}$ were the dominate channel erosion in all hillslopes with understory-degradation, and small gullies (depth $>0.3 \mathrm{~m}$ ) with a width $0.5-1.0 \mathrm{~m}$ were found at the locations of hillslopes with high understory-degradation. Channel density and soil loss rate increased with the increase in understory-degradation in the forested hillslopes. Simple correlation analysis indicated that channel density was negatively correlated with fine root density (diameter $<$ $1 \mathrm{~mm}$ and $1-2 \mathrm{~mm}$ ) and grass and shrub covers, but not with coarse roots (diam. 2-5 mm and 5-10 mm) and mulch and tree covers. The principal component regression revealed fine root density (diam. $<1 \mathrm{~mm}$ ), shrub and grass covers were the most important predictors for channel density in the forested hillslopes. Tree cover, mulch cover and coarse root density were found to have much less influence on channel density. For the model established from this study using principle component regression, vegetation variables could explain $82 \%$ variance of channel density. 
Conclusions We conclude that fine root density and grass and shrub covers are the most important factors in controlling soil erosions in forested hillslopes. These parameters should be taken into consideration in assessing reforestation for soil erosion control in hilly areas such as that in southwestern China or other similar regions.

Keywords Channel density · Fine root · Rill and gully erosion · Grass and shrub cover $\cdot$ Forest hillslope $\cdot$ China

\section{Introduction}

Channel (rill and gully) erosion by concentrated overland flow is a global concern as it leads to increased sediment production and land degradation (Poesen et al. 1998; Li et al. 2004; Valentin et al. 2005). Through source tracking, researchers in Australia and China have found that the majority of sediments in watersheds are produced by gully erosion (Li et al. 2003; Hughes et al. 2009). Understanding the factors that cause channel initiation in a landscape can lead to development of improved management practices that can increase productivity and ecosystem services of the land (Poesen et al. 1998).

Channel initiation could be related to a wide range of factors, including rainfall intensity, flow hydraulics, topography, soil texture, surface features, vegetation and land use (Valentin et al. 2005; Kirkby and Bracken 2009). Vandekerckhove et al. (2000) found that gully initiation in Mediterranean areas was more dependent on vegetation type and the extent of cover than rainfall amount. In semiarid central Mexico, Rebeca et al. (2010) reported that runoff and soil erosion were reduced by vegetation patches. Moreno-de las Heras et al. (2009) found that a $50 \%$ vegetation cover was the threshold for channel initiation in reclaimed mining soils in Spain. . Surface vegetation reduces waterinduced soil erosion by intercepting runoff, increasing water infiltration, and retarding flow velocities (Styczen and Morgan 1995). Sorriso-Valvo et al. (1995) found that ground plant cover more effective than canopy cover in controlling runoff and erosion. In a forest, interception of rain by tall trees may form larger and higher kinetic energy drops, and thus, the tree coverage might even favor soil crusting, runoff generation and gully initiation (Hall and Calder 1993). The myriad roles that vegetation cover plays in protecting soils from erosion indicate that vegetation functions in a highly complex manner that is best addressed by considering the interaction of multiple variables.

Roots also play a critical role with respect to soil erosion control (Li 1995; Ghidey and Alberts 1997; De Baets et al. 2007). Plant roots enlace and concrete soil, and this can stabilize soil structure and limit soil movement (Tengbeh 1993). A study by Archibold et al. (2003) found that gully retreat was delayed by tree root mats that bound surface soil. Plant roots can also indirectly improve soil hydrological characteristics, therefore, reducing concentrated flow erosion. Gyssels and Poesen (2003) showed that an increase in shoot and root density resulted in an exponential decrease of concentrated flow erosion rates. Gray (1978) noted there was a non-linear inverse relationship between root diameter and strength, thus smaller roots could contribute more strength per unit root area in relation to control of channel initiation. Li et al. (1991) defined effective roots (i.e. those that inhibit erosion) as having fibrils less than $1 \mathrm{~mm}$ in diameter, and densely distributed at depths of 0-30 cm. Poesen et al. (2006) pointed out below ground biomass mechanisms should be considered in models predicting soil erosion. Yet, little is known about the effects of fine roots along with shrub and grass cover on channel erosion in forest hillslopes (Valentin et al. 2005; Poesen et al. 2006).

China manages the world's largest forest plantations (Piao et al. 2009) with the objectives of controlling soil erosion through the establishment of tree canopies. However, many forested hillslopes in southwestern China are still experiencing rill and gully erosion (Zhao 2006). For instance, in the Changshanling mountain area (800 ha) in southwestern China gullies occupy $13 \%$ of the forested land area. Human activity mainly (litterfall extraction and livestock grazing) have severely impacted the forested hillslopes of southwestern China. Grazing in the forest was known to reduce the density and biomass of grass grown under trees, and livestock could compact soil and retard root development (Belsky and Blumenthal 1997), thus causing degradation of understory in the forest. The degradation of understory as the loss of grass and shrub cover and possibly the fine root biomass could have contributed to the channel erosion in the hillslope forest of southwestern China. However, little is known about understory cover, root biomass and their relationship with channel erosion in the large forested region, and so far, this issue has not been considered in assessing the role of Chinese reforestation. Our investigation of the Xinying catchment, located in the Changshanling mountain area of southwestern China, began with the hypothesis that the 
extent of forested hillslope erosion depends on fine root and contact cover of shrub and grass, given the same climate, topsoil and topographic conditions.

The objectives of the present study were to (1) investigate spatial variations in channel density, root density and vegetation cover across forested hillslopes with a wide range of understory degradation; (2) evaluate the importance of fine root density and grass and shrub cover variables relative to other vegetation factors in relation to channel erosion; and (3) establish relationships between root density, vegetation cover and channel density in forested hillslopes.

\section{Materials and methods}

Study area and experimental design

The study area is located in the Xinying catchment of the Changshanling mountain area $\left(27^{\circ} 43^{\prime} \mathrm{N}, 102^{\circ} 13^{\prime}\right.$ E), $20 \mathrm{~km}$ south of Xichang City, Sichuan province, southwestern China with altitudes of 1450 to $1706 \mathrm{~m}$. The area has a subtropical monsoon climate with a mean annual temperature of $17.1^{\circ} \mathrm{C}$ and an annual rainfall of $1013 \mathrm{~mm}$ with approximately two thirds of the rainfall occurring between June and October (Yang et al. 2002). The soil was derived from purple sandstone that is easily eroded, and it has a mean depth of $30 \mathrm{~cm}$. The soil texture is generally silty loam.

The original forest on these hillslopes was lost due to tree-cutting for "steel making" in 1958. The present dominate vegetation in the forested hillslope was trees (Pinus massoniana Lamb) and shrubs (Camellia oleifera Abel) air-planted during the 1970's, and warm season native grass (Eulaliopsis) (Table 1). Pinus massoniana is a common tree species in plantation forestry areas to replace or compensate for natural forest loss in southern China. It is an evergreen coniferous tree with a height of 2-8 m, a broad, rounded crown of 2 to $5 \mathrm{~m}$ in diameter, and a scaly, plated trunk. The shrub C. oleifera with upright, multiple trunks and branches, and oval vase crown reaches a height of less than one meter. The grass Eulaliopsis is an upright, dense-tuft perennial species, which has predominantly fibrous roots (Liu 2006). Shrubs and grasses as the understory of the forest serve as contact cover. Root biomass with diameter $<2 \mathrm{~mm}$ increased in the order of tree $<$ shrub $<$ grass, whereas coarse roots with diameter $>2 \mathrm{~mm}$ followed the inverse trend (Table 1). Shallow soil layers $(30 \mathrm{~cm})$ restrict plant root growth in the forested hillslopes and over $50 \%$ of roots were concentrated in 0-20 cm soil depth.

Frequent human activities (mainly the extraction of litterfall) and grazing by open-raising sheep and cattle have occurred in the forested area (Table 2). Grazing had resulted in the degradation of understory on the hillslope forest, which was increased in areas closer in proximity to the village. Based on different degrees of animal grazing and litter extraction established through discussion with farmers and a field survey, we selected four complete hillslopes representing four levels of understory-degradation: no understory-degradation (control), light understory-degradation, intermediate understorydegradation, and high understory-degradation. As shown in Table 2, the four hillslopes had similar slope degree $\left(19.5-21.9^{\circ}\right)$ and slope aspects $\left(109-113^{\circ}\right)$. To increase the variation in understory-vegetation and channel density in favor of the establishment of vegetation-channel density model, each hillslope was divided into three sections: upper, middle and lower for sampling and observation. The assumption of variations in understory-vegetation and channel density among slope positions is sound, as the slope position can affect the accessibility to people for litterfall extraction and animals for grazing. The four hillslopes had no foothills or significant depositional zones.

Table 1 Growth characteristics of each vegetation type and its contribution to total root biomass in forested hillslopes of southwestern China

\begin{tabular}{|c|c|c|c|c|c|c|}
\hline \multirow[t]{2}{*}{ Type } & \multirow[t]{2}{*}{ Species } & \multirow[t]{2}{*}{ Crown width } & \multirow[t]{2}{*}{ Diameter $^{\mathrm{a}}$} & \multirow[t]{2}{*}{ Height } & \multicolumn{2}{|c|}{ Root biomass distribution } \\
\hline & & & & & Diam. $<2 \mathrm{~mm}$ & Diam. $>2 \mathrm{~mm}$ \\
\hline Tree & Pinus massoniana Lamb & $1.8-5.0$ & $0.26-0.69$ & $2.1-8.0$ & $7-9$ & $27-29$ \\
\hline Shrub & Camellia oleifera Abel & $0.18-0.9$ & - & $0.19-0.84$ & $9-12$ & $26-27$ \\
\hline Grass & Eulaliopsis & - & - & $0.4-1.0$ & $18-33$ & $11-21$ \\
\hline
\end{tabular}

${ }^{\mathrm{a}}$ It was measured at breast height 
Table 2 Hillslopes and positions selected for the study and reasons for understory degradation

\begin{tabular}{|c|c|c|c|c|c|}
\hline Hillslope & Position & Size $\left(\mathrm{m}^{2}\right)$ & $\begin{array}{l}\text { Slope } \\
\text { degree }\left(^{\circ}\right)\end{array}$ & $\begin{array}{l}\text { Aspect } \\
\left({ }^{\circ}\right)\end{array}$ & Understory degradation reason \\
\hline \multirow{3}{*}{$\begin{array}{l}\text { Control } \\
\text { (No understory-degradation) }\end{array}$} & Upper & $12 \times 18$ & 21.0 & \multirow[t]{3}{*}{109} & \multirow[t]{3}{*}{ Rare grazing or litter extraction } \\
\hline & Middle & $14 \times 18$ & 19.6 & & \\
\hline & Lower & $13 \times 18$ & 18.0 & & \\
\hline \multirow[t]{3}{*}{ Light understory-degradation } & Upper & $16 \times 29$ & 22.9 & \multirow[t]{3}{*}{110} & \multirow{3}{*}{$\begin{array}{l}\text { Occasionally grazing or extracting litter at the lower } \\
\text { hillslope }\end{array}$} \\
\hline & Middle & $14 \times 29$ & 23.4 & & \\
\hline & Lower & $20 \times 29$ & 19.6 & & \\
\hline \multirow[t]{3}{*}{ Intermediate understory -degradation } & Upper & $20 \times 20$ & 21.2 & \multirow[t]{3}{*}{113} & \multirow[t]{3}{*}{ Some litter extraction at the lower and middle hillslope } \\
\hline & Middle & $20 \times 20$ & 22.1 & & \\
\hline & Lower & $19 \times 20$ & 19.0 & & \\
\hline \multirow[t]{3}{*}{ High understory-degradation } & Upper & $15 \times 34$ & 22.1 & \multirow[t]{3}{*}{111} & \multirow[t]{3}{*}{ Intensive grazing over the entire hillslope } \\
\hline & Middle & $16 \times 34$ & 23.6 & & \\
\hline & Lower & $16 \times 34$ & 19.3 & & \\
\hline
\end{tabular}

Measurement and sampling

A passage in the soil with a depth of $2 \mathrm{~cm}$ or greater was considered as channel. In each sampling site, we measured the length of all channels using measuring tapes. The channel erosion was expressed as channel density, which was defined as total length of channels within a unit soil surface area $\left(\mathrm{m} \mathrm{m}^{-2}\right)$ (Valentin et al. 2005). The width and depth of channels were also measured in the study.

Soil loss rate was estimated by the ${ }^{137} \mathrm{Cs}$ fallout technique (Walling and He 1997). Soil cores were collected at the depth of $0-30 \mathrm{~cm}$, which could penetrate the full depth of ${ }^{137} \mathrm{Cs}$ profile. The soil core samples were also collected at undisturbed grasslands at the summit of each hillslope as a reference for determining the local input of the ${ }^{137} \mathrm{Cs}$ inventory. The reference sites have remained undisturbed for more than 200 years. The soil samples were air-dried and ground to pass through a $2 \mathrm{~mm}$ sieve. The subsamples were used to measure the soil moisture for calculating soil bulk density. The activity of ${ }^{137} \mathrm{Cs}$ in soil was measured using a hyper pure Ge detector (BE5030) coupled to a multi-channel analyzer (CANBERRA, USA). The ${ }^{137} \mathrm{Cs}$ activity was detected at $662 \mathrm{keV}$ peak using counting time over $80,000 \mathrm{~s}$, which provided an analytical precision of $\pm 5 \%$ for ${ }^{137} \mathrm{Cs}$ (Li et al. 2006). At each sampling point, the ${ }^{137} \mathrm{Cs}$ inventory was calculated as follows: ${ }^{137} \mathrm{Cs}$ $\left(\mathrm{Bq} \mathrm{m}^{-2}\right)=$ [activity $\left(\mathrm{Bq} \mathrm{kg}{ }^{-1}\right) *$ total weight of ovendry soil for the entire core $(\mathrm{kg})] /$ sampling area $\left(\mathrm{m}^{2}\right)$. Soil loss rate was determined based on the change in the ${ }^{137} \mathrm{Cs}$ inventory relative to the reference using the diffusion and migration model in Walling and He (1997).
Vegetation cover was divided amongst four categories: tree cover ( $>2 \mathrm{~m}$ height), shrub cover, and grass and mulch cover. Vegetation cover was determined by the line transect method (Lutes 2002; Allredge and Gates 1985). A long tape with a $10 \mathrm{~cm}$ observation interval was used. The length of transects ranged from 12 to $38 \mathrm{~m}$, depending on plot size and transect orientation.

Root density was measured using soil core samples at two depths: $0-15 \mathrm{~cm}$ and $15-30 \mathrm{~cm}$. A steel coring device $(8 \mathrm{~cm}$ diameter) lined with a steel tube $(\mathrm{Bi}-$ partite root auger) was inserted into the soil using a sledge hammer to obtain soil core samples. Soil coring was conducted in inter-channel areas near trees and shrubs, within grass and bare ground. Three soil cores were taken around a tree or shrub or randomly from grassy areas to be composited as one sample. In each sampling site, there were four root samples from tree, shrub, grass and bared areas. The collection of roots from soil cores and separation into various diameter classes were conducted using the rinsing method as described in $\mathrm{Li}$ et al. (1991, 1992). Briefly, soil core samples were placed in a soil sieve of $0.5 \mathrm{~mm}$ mesh and rinsed by water to remove the soil. Each root in the sieve was taken out and measured in diameter with a vernier caliper. Then, the roots were grouped into four diameter classes: $<1 \mathrm{~mm}, 1-2 \mathrm{~mm}, 2-5 \mathrm{~mm}, 5-10 \mathrm{~mm}$. The roots in each diameter class were then oven-dried at $60-70{ }^{\circ} \mathrm{C}$ for 16-20 $\mathrm{h}$ and weighed using a digital balance. The root density $\left(\mathrm{mg} \mathrm{dm}^{-3}\right)$ for a given vegetation type was calculated as the total root mass within $0-30 \mathrm{~cm}$ soil depth divided by the total core volume. The calculation was performed individually for each root size. The total 
root density (RD) per root size in a sampling site was the sum of root density of each vegetation type weighted by vegetation cover as below:

$\mathrm{RD}=\sum_{i=1}^{4} R D i * V C i$

where $\mathrm{i}$ is plant type, 1 for tree, 2 for shrub, 3 for grass and 4 for bare; VC ground cover rate of a given vegetation type.

Statistical analysis

Observations and samplings in each sampling site were conducted with four replications, from which mean and SE were calculated. We created one dependent variable (channel density) and eight independent variables that included the densities of four root diameter classes ( $<1 \mathrm{~mm}, 1-2 \mathrm{~mm}, 2-5 \mathrm{~mm}, 5-10 \mathrm{~mm}$ ), and covers of four vegetation types (tree cover, shrub cover, grass cover, and mulch cover).

To identify the major vegetation factors controlling channel density, we performed principal component regression (PCR), which could remove multicolinearity among independent variables (Fekedulegn et al. 2002). First, principal component analysis (PCA) was used to transform the original vegetation variables into a new set of variables called principal components, which could explain some variations of the data set. Then, using PCR, we performed a multiple regression analysis of the response variable (channel density) against the set of principal components of the highest ranking that could totally explain $85 \%$ of variations. Because the principal components were pairwise independent, multiple linear regression procedure was valid. At last, the regression coefficients for the principal components were transformed back to obtain a set of coefficients that corresponded to the original variables to form the channel density - vegetation model.

\section{Results}

Channel morphometrics

As shown in Table 3, length, width, and depth of channels in four hillslopes ranged from 0.2 to $25.2 \mathrm{~m}, 0.03$ to $2.2 \mathrm{~m}$ and 0.01 to $0.7 \mathrm{~m}$, respectively, and that no channels were observed in control. A 22 and $26 \%$ increase were shown for average length and depth of channels, respectively, from the hillslope with light understory-degradation to that with intermediate understory-degradation. A much greater increase of $460 \%$ (average channel length) and $35 \%$ (average channel depth) was found from the hillslope with intermediate understory-degradation to that with high understorydegradation. Rilling was the dominate channel erosion feature in the three hillslopes with understory-degradation. Gullies were only identified at the middle and upper plots of the hillslope with high understory-

Table 3 Morphometric parameters of channel (rill or gully) at sampling sites of forested hillslopes

\begin{tabular}{|c|c|c|c|c|c|c|c|c|c|c|}
\hline \multirow[t]{2}{*}{ Hillslopes } & \multirow[t]{2}{*}{ Position } & \multicolumn{3}{|c|}{ Length (m) } & \multicolumn{3}{|c|}{ Width (m) } & \multicolumn{3}{|c|}{ Depth (m) } \\
\hline & & $\min$ & $\max$ & average & $\min$ & $\max$ & average & $\min$ & $\max$ & average \\
\hline \multirow{3}{*}{$\begin{array}{l}\text { Control } \\
\text { (No understory-degradation) }\end{array}$} & Upper & 0 & 0 & 0 & 0 & 0 & 0 & 0 & 0 & 0 \\
\hline & Middle & 0 & 0 & 0 & 0 & 0 & 0 & 0 & 0 & 0 \\
\hline & Lower & 0 & 0 & 0 & 0 & 0 & 0 & 0 & 0 & 0 \\
\hline \multirow[t]{3}{*}{ Light understory-degradation } & Upper & 0.1 & 2.5 & $1.9 \pm 0.1$ & 0.06 & 0.10 & $0.09 \pm 0.003$ & 0.01 & 0.11 & $0.11 \pm 0.01$ \\
\hline & Middle & 0.3 & 2.0 & $2.0 \pm 0.03$ & 0.05 & 0.20 & $0.08 \pm 0.001$ & 0.01 & 0.18 & $0.09 \pm 0.00$ \\
\hline & Lower & 0.2 & 3.2 & $1.2 \pm 0.01$ & 0.03 & 0.08 & $0.04 \pm 0.001$ & 0.01 & 0.08 & $0.05 \pm 0.01$ \\
\hline \multirow[t]{3}{*}{ Intermediate understory-degradation } & Upper & 0.6 & 3.1 & $2.2 \pm 0.1$ & 0.63 & 2.0 & $1.01 \pm 0.05$ & 0.05 & 0.28 & $0.14 \pm 0.01$ \\
\hline & Middle & 1.0 & 3.0 & $2.2 \pm 0.1$ & 0.56 & 1.4 & $0.80 \pm 0.03$ & 0.05 & 0.29 & $0.12 \pm 0.01$ \\
\hline & Lower & 0.7 & 3.0 & $2.0 \pm .0 .1$ & 0.45 & 1.1 & $0.71 \pm 0.02$ & 0.03 & 0.17 & $0.07 \pm 0.00$ \\
\hline \multirow[t]{3}{*}{ High understory-degradation } & Upper & 3.3 & 25.2 & $11.3 \pm 2.0$ & 0.31 & 2.1 & $0.89 \pm 0.05$ & 0.03 & 0.70 & $0.17 \pm 0.02$ \\
\hline & Middle & 3.0 & 23.0 & $11.2 \pm 1.8$ & 0.30 & 2.2 & $0.88 \pm 0.06$ & 0.04 & 0.54 & $0.16 \pm 0.02$ \\
\hline & Lower & 3.0 & 22.5 & $12.3 \pm 1.8$ & 0.20 & 1.1 & $0.56 \pm 0.08$ & 0.02 & 0.30 & $0.11 \pm 0.03$ \\
\hline
\end{tabular}


degradation, where a small number of channels were deeper than $0.3 \mathrm{~m}$.

Channel density and soil loss rate

The four different hillslopes had great variability in channel density (Table 4). The forested hillslope with high understory-degradation had the largest channel density $\left(0.31 \pm 0.05 \mathrm{~m} \mathrm{~m}^{-2}\right)$. The forestland with intermediate understory-degradation had a slightly lower channel density $\left(0.23 \pm 0.03 \mathrm{~m} \mathrm{~m}^{-2}\right)$. The hillslopes with either light or no understory-degradation had channel densities of $0.12 \pm 0.06 \mathrm{~m} \mathrm{~m}^{-2}$ and $0 \mathrm{~m} \mathrm{~m}^{-2}$, respectively. Thus, channel densities in the intermediate and high understory-degradation forestlands were 2 and 2.6 times greater, respectively, than those of light understorydegradation forestland.

Distinctive spatial patterns in channel density were also observed at various points of a hillslope (Table 4). Channel density for the middle and lower plots of the hillslope with high understory-degradation were 77 and $60 \%$ greater than that for upper plots $(0.21 \pm$ $0.00 \mathrm{~m} \mathrm{~m}^{-2}$ ), respectively. Among intermediate understory-degradation hillslope, channel density increased by 10 to $42 \%$ from the upper plot $\left(0.20 \mathrm{~m} \mathrm{~m}^{-2}\right)$ through the middle plot to the lower plot. In contrast, channel densities for the hillslope with light understory-degradation forestland had values ranging from 0.11 to $0.13 \mathrm{~m} \mathrm{~m}^{-2}$ which did not vary significantly at different points along the hillslope.

Based on ${ }^{137} \mathrm{Cs}$ analysis, the potential soil loss rate ranged from -2.3 to $0.1 \mathrm{Mg} \mathrm{ha}^{-1}$ year $^{-1}$ at the control hillslope, -2 to $4 \mathrm{Mg} \mathrm{ha}^{-1}$ year $^{-1}$ at hillslopes with light understory-degradation, -0.1 to $12 \mathrm{Mg} \mathrm{ha}^{-1}$ year $^{-1}$ at hillslopes with intermediate understory-degradation, and 71 to $143 \mathrm{Mg} \mathrm{ha}^{-1}$ year $^{-1}$ at hillslopes with high understory-degradation (Table 4). The results show that channel density among four slopes and slope positions generally increased with the increase in soil loss rate.

\section{Vegetation cover}

Vegetation cover varied considerably among the four hillslopes and the three positions (Table 4). The forestland with high understory-degradation had the smallest cover by all other vegetation types. Hillslopes with intermediate understory-degradation had the most extensive tree cover $(65 \%)$ and smallest shrub $(9 \%)$ and grass cover $(21 \%)$, as compared to those with light or no understory-degradation. The light understorydegradation hillslope had shrub and grass covers of 19 and $65 \%$, and no understory-degradation hillslope had shrub and grass covers of 28 and $97 \%$. These percentages were four to six times (shrub cover) and five to seven times (grass cover) greater than respective values for the high understory-degradation hillslope. Mulch cover was found to be high relative to other vegetation types (ranging from 64 to $76 \%$ ) for most hillslopes, except in areas of high understory-degradation (31\%).

Tree cover slightly increased from the middle to downslope on hillslope with intermediate understorydegradation (Table 4). A decreasing trend (33 to $55 \%$ ) for mulch cover was found downslope on high and light understory-degradation hillslopes. In contrast, mulch cover on the hillslope with no understory-degradation showed a significant downslope increase (169\%). Shrub cover on the high understory-degradation hillslope increased downslope by a factor of 1.9 times, while a decreasing trend was identified from the upper to lower positions on the other three hillslopes. Grass cover decreased by $32 \%$ from the upper to lower positions on the intermediate understory-degradation hillslope. No significant variations along slope in grass cover were observed for hillslopes with light and no understory-degradations.

Channel density was found to be more strongly related to grass and shrub cover (Fig. 1a \& b). There was no significant correlation between channel density and tree and mulch covers. Channel density decreased with the increase in grass and shrub cover according to a logarithmic regression equation. The inverse relationship between channel density and grass cover appears to function discretely (Fig. 1a). The channel density decreased rapidly when grass cover increased from 10 to $30 \%$. For grass cover values above $30 \%$, channel density decreased more gradually. The relationship between channel density and shrub cover indicates that shrub cover values of more than $20 \%$ would cause a sharp reduction in channel density (Fig. 1b). Relative to grass cover, shrub cover appears to exert a stronger influence in reducing channel density.

\section{Root density}

Total root density in forested hillslopes was found to decrease along with the increase in understorydegradation (i.e. no, light, intermediate and high understory-degradation) based on data in Table 4. The 


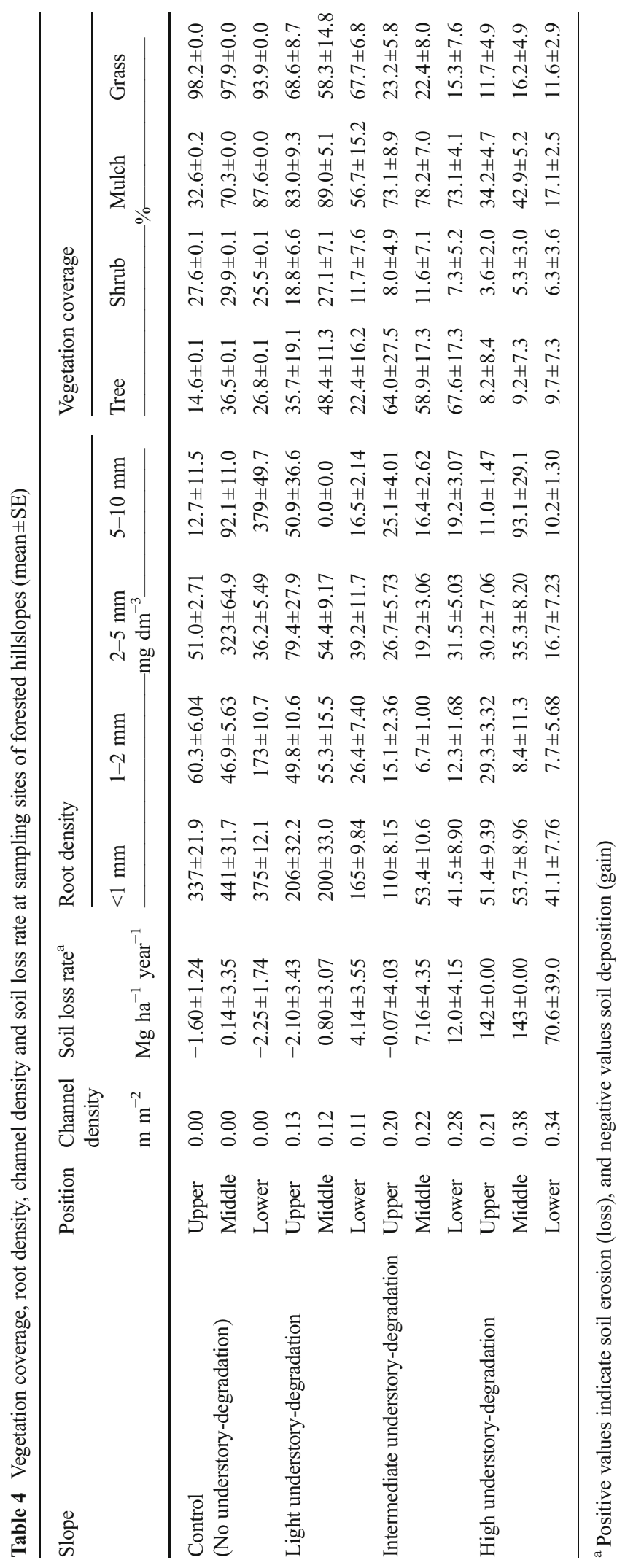



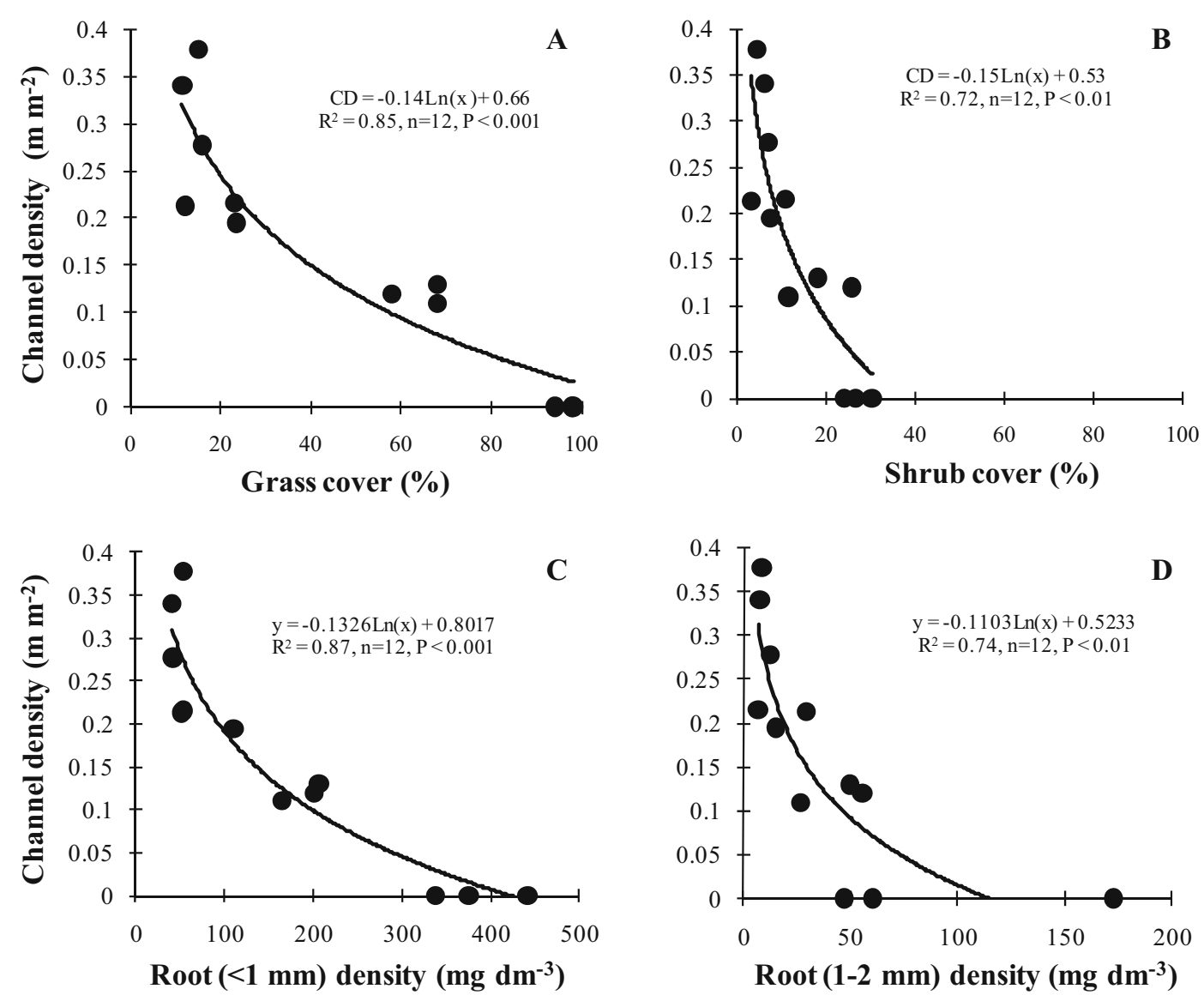

Fig. 1 Simple correlation between channel density and vegetation variables at forested hillslopes of southwestern China, which is significant at $P<0.05$ level. CD stands for channel density

decrease in root density along with the understory degradation in forested hillslope found to be most pronounced for fine root $(<1 \mathrm{~mm})$. Total root density values for all root diameter classes were observed to decrease from the upper slope portions of the hillslope to the middle and lower slope positions. Total root density decreased by around 39-50\% from the upper slope positions to the lower portions on hillslopes with light, intermediate and high understory-degradation. In contrast, on the no understory-degradation hillslopes, root density values showed an increasing trend downslope.

Channel density decreased with fine root $(<1 \mathrm{~mm})$ density with a piecewise relationship of three discrete domains (Fig. 1c). When fine root density increased from 24 to $140 \mathrm{mg} \mathrm{dm}^{-3}$, channel density decreased by $60 \%$. At fine root density between 140 and $320 \mathrm{mg} \mathrm{dm}{ }^{-3}$, channel density decreased from 60 to $90 \%$ as compared to that at fine root density of $24 \mathrm{mg} \mathrm{dm}^{-3}$. For fine root density greater than $320 \mathrm{mg} \mathrm{dm}^{-3}$, channel density decreased at an extremely low rate. Channel density sharply declined with the increase in root density for diameter 1-2 mm (Fig. 1d). No significant correlation was found between channel density and root density of diameters $2-5 \mathrm{~mm}$ and $5-10 \mathrm{~mm}$.

\section{Principal component regression}

The vegetation variables as independents for predicting the channel density (dependent) were correlated themselves (colinearity) (Pearson' correlation coefficient not shown), and thus, principal component analysis/ regression was used to identify vegetation variables that have significant influence on channel density. The principal component analysis (PCA) showed principal component (PC) 1, 2 and 3 were important as they had eigenvalues of above 1.0 (5.20 for PC1, 1.67 for PC2, and 1.30 for PC3). The first principal component (PC1) accounted for $57.7 \%$ of the total variation of the eight vegetation variables. In $\mathrm{PC} 1$, the vegetation variables 
that had loadings of above 0.4 were fine $\operatorname{root}(<1 \mathrm{~mm})$ density, shrub cover and grass cover (Table 5). We interpreted PC1 as the overall soil resistance to concentrated flow supported by enlacing of fine roots and rainfall interception by shrub and grass cover. The second principal component, which accounted for $18.6 \%$ of the total variation of the eight vegetation variables, was controlled by tree cover and mulch cover. The PC2 can be interpreted as the measurement for concentrated runoff caused by stem flow and densely formed mattress of pine needles. The third principal component, which accounted for $14.4 \%$ of the total variation of the eight vegetation variables, can be considered as the root tensile strength of coarse roots.

Principal component regression (PCR) was then performed to determine if all three PCs should be included in the prediction of channel prediction as: $\mathrm{y}=\mathrm{a}+\mathrm{bPC} \mathrm{C}_{1}+$ $\mathrm{cPC}_{2}+\mathrm{dPC}_{3}$. The regression results indicate that only PC1 had a t-value with $P<0.05$ (Table 6), and thus only PC1 could be included in the prediction of channel density. Since the major contributing factors for PC1 were fine root density, shrub cover and grass cover, these three factors largely related to understory are most important in controlling the channel initiation in forested hillslopes. Other factors such as tree cover and mulch cover in PC2 and coarse roots in PC3 would have no major influence on the channel density in forested land. After PC coefficients were transformed to those for original vegetation variables listed in Table 5, we obtained the channel density prediction model as $\mathrm{y}=9.021$ -

Table 5 Principal component (PC) with eigenvalues above 1.0 and loadings of vegetation variables on a PC

\begin{tabular}{|c|c|c|c|}
\hline Variable & $\mathrm{PC} 1^{\mathrm{a}}$ & $\mathrm{PC} 2$ & $\mathrm{PC} 3$ \\
\hline $\mathrm{X} 1(\mathrm{RD}<1 \mathrm{~mm} \text { diam. })^{\mathrm{b}}$ & 0.4578 & -0.1363 & 0.1486 \\
\hline$X 2$ (RD 1-2 mm diam.) & 0.3924 & -0.0607 & -0.4823 \\
\hline X3 (RD 2-5 mm diam.) & 0.2727 & -0.0577 & 0.6151 \\
\hline X4 (RD 5-10 mm diam.) & 0.3461 & 0.0372 & -0.5254 \\
\hline X5 (tree cover) & 0.0093 & 0.7421 & 0.1461 \\
\hline X6 (shrub cover) & 0.434 & -0.0217 & 0.2283 \\
\hline X7 (mulch cover) & 0.241 & 0.6345 & -0.0655 \\
\hline X8 (grass cover) & 0.4424 & -0.1387 & 0.1146 \\
\hline
\end{tabular}

${ }^{\text {a }} P C$ principal component

${ }^{\mathrm{b}} R D$ root density

${ }^{\mathrm{c}}$ Bold indicates the loading is above 0.4, the standard for a key contributor in PCA analysis
Table 6 Regression of channel density against the principal components

\begin{tabular}{lccl}
\hline Variable & Parameter estimate & $t$ value & $\operatorname{Pr}>\mathrm{t}$ \\
\hline Intercept & $5.75 \mathrm{E}-16$ & $3.96 \mathrm{E}-15$ & 1.00 \\
PC1 & -0.427 & -5.92 & 0.000354 \\
PC2 & 0.035 & 0.299 & 0.772 \\
PC3 & -0.085 & -0.636 & 0.543 \\
\hline
\end{tabular}

$0.018 X 1-0.019 \times 2-0.019 \times 3-0.01 X 4+0.002 \times 5-$ 0.066 X6-0.015X7-0.034X8 $\left(R^{2}=0.82, P<0.001\right)$.

\section{Discussion}

In this study, we found that channel density in the forested hillslope was inversely related to grass and shrub covers and fine root density. This supports the hypothesis that forested hillslopes lacking of grass and shrub cover (understory) and fine roots are vulnerable to soil erosion. The increase in channel erosion and soil loss from light to high understory-degradation hillslopes was clearly associated with the low understory cover and fine root density. This effect is also evident in variations in understory cover, fine root density and channel erosion with different slope positions. For hillslopes with understory degradation in this study, understory cover and fine root density were generally lower from the upper to lower slopes. In a hillslope, the lower slope is easily accessible to people and animals, resulting in higher litter extraction and grazing, respectively (Table 1). Thus, the increase in channel density and soil loss from the upper to lower slopes could be explained by the increase in understory degradation driven by better accessibility to human activities and animals grazing.

Loss of vegetation cover and removal of leaf litter led to the formation of soil seals (Singer and Bissonnais 1998) and exposure of soil particles to the direct impact of raindrops (Mohammad and Mohammad 2010), both of which enhance runoff and soil erosion (Descroix et al. 2001, 2008; Snyman and duPreez 2005; Al-Seikh 2006). Overgrazing and cattle movement were the main causes of gully erosion in mountainous areas (Descroix et al. 2008). Models described here showed that dwarf shrub cover and grass cover were more effective than tree cover in preventing channel initiation, indicating that the type of vegetation is an important factor to 
erosion control. Although tree cover intercepts rain droplets (Coppin and Richards 1990; Simon and Collison 2002), it may not be effective for coniferous species. Pine needles above ground divert rain droplets, and the narrow-shaped and densely interlaced pineneedle mattress on the soil surface decreases the water infiltration capacity. Pine species in this study mainly serve to concentrate surface runoff from stem flow. Nunes et al. (2011) also reported serious runoff and soil erosion from land afforested with pines in Portugal. In such coniferous forests, the understory is especially important for controlling soil erosion. Even in situations where the forest is established on the hillslope, if there is understory degradation, soil erosion would still pose a problem. This issue needs to be taken into consideration in reforestation planning and assessment. In forestlands, overgrazing and litterfall extraction should be avoided or minimized to ensure adequate understorey for controlling soil erosion.

The significant inverse relationship between fine root $(<1 \mathrm{~mm})$ density and channel density revealed in the study further emphasizes the role of fine roots in controlling soil erosion by concentrated flow, which was initially observed in laboratory and plot experiments ( $\mathrm{Li}$ et al. 1991; Gyssels et al. 2005). Using the flume method, Li et al. (1991) found that the ability of plant roots to mitigate concentrated flow erosion mainly depended on the presence and distribution of 'effective' roots $(<1 \mathrm{~mm})$ in the top $50 \mathrm{~cm}$ of the soil. Gyssels et al. (2005) showed that while dense root systems produced by a mix of small trees, shrubs, and grasses were important in maintaining slope stability, shallow dense root networks produced by grasses appear to be more effective in protecting soils from water erosion by concentrated flow. It is also the case that fine and small roots $(0.5-$ $2.0 \mathrm{~mm}$ in diameter) at deeper soils (root depth $>30 \mathrm{~cm}$ ) with high tensile strength, especially for tree species, are more efficient in supporting stream bank stability (Davidson et al. 1989; Wynn et al. 2004; Wynn and Mostaghimi 2006). The grasses and shrubs are optimum cover types for slope stabilization largely due to their large numbers of small, strong roots (Li. 1995; Dabney et al. 1997). Thus, shallow and densely distributed fine roots (root depth $<30 \mathrm{~cm}$ ), especially for herbaceous species, played the most important role in control of channel initiation by concentrated overland flow. De Baets and Poesen (2010) reported the erosion-reducing effect by roots was well explained by fibrous roots, but not tap roots. $\mathrm{Li}$ (1995) reported that only fine roots $(<1 \mathrm{~mm})$ can effectively contribute to the improvement of soil noncapillary porosity and the formation of water-stable aggregates of $2-5 \mathrm{~mm}$ and $>5 \mathrm{~mm}$. The fine roots generally have larger surface area than coarse roots, and this might have allowed fine roots to have greater binding ability in the aggregate formation. Although fine roots were apparently the most important variable in controlling soil erosion in forested hillslopes, our results also showed some contribution of coarse roots in reducing the channel density, and thus they should also be considered in soil erosion control. Simon and Collison (2002) found most of the root strength under woody species came from larger ( $>5 \mathrm{~mm}$ diameter) roots.

The majority of previous studies have addressed the role of plant roots and vegetation cover separately in affecting soil erosion (Li et al. 1991; Flanagan and Nearing 1995; Renard et al. 1997). This study has integrated the combined influence of root density and shrub and grass vegetation covers on channel density in the forested land in a single model. The model generated can be used for predicting channel density and evaluating soil erosion in forested hillslopes.

\section{Conclusions}

Based on the results from this study, we conclude that plant fine roots $(<1 \mathrm{~mm})$ and grass and shrub vegetation cover are major factors in determining soil erosion in forested hillslopes in southwestern China. In hillslope afforested with coniferous species, maintenance of a good understory through reduction of grazing and litter extraction is crucial for controlling soil erosion. Understory with $60 \%$ grass coverage and $20 \%$ shrub coverage is needed to prevent channel initiation in forested hillslopes. The model generated from this study using principle component regression can be applied to assess channel erosion in forestland in southwestern China and other similar sites in other regions. Our results suggest that quantification of fine root along with grass and shrub covers in forested hillslopes would be needed to assess the role of Chinese reforestation in soil erosion control and in understanding the mechanism of channel initiation in forestland.

Acknowledgments This study was supported by the National Natural Science Foundation of China (No. 41171231 and No.31000944), "Twelfth five-year" National Science and Technology Support Plan (2013BAD11B03), and Basic Research Program of China (2014CB932203). We thank Dr. Adrian Chappell, 
two anonymous reviewers, and section editor, Dr. Alexia Stockes for providing constructive comments, which have improved the manuscript.

Open Access This article is distributed under the terms of the Creative Commons Attribution License which permits any use, distribution, and reproduction in any medium, provided the original author(s) and the source are credited.

\section{References}

Allredge JR, Gates CE (1985) Line transect estimators for lefttruncated distributions. Biometrics 41:273-280

Al-Seikh S (2006) The Effect of different water harvesting techniques on Runoff, Sedimentation, and soil characteristics. M.Sc thesis, Hebron University

Archibold OW, Levesque LMJ, de Boer DH, Aitken AE, Delanoy L (2003) Gully retreat in a semi urban catchment in Saskatoon, Saskatchewan. Appl Geogr 23:261-279

Belsky AJ, Blumenthal DM (1997) Effect of livestock grazing on stand dynamics and soils in Upland forest of the Interior West. Conserv Biol 11:315-327

Coppin NJ, Richards IG (1990) Use of vegetation in civil engineering. Butterworth-Heinemann, Oxford

Dabney SM, Meyer LD, McGregor KC (1997) Sediment control and landscape modification with grass hedges. In: Wang SY, Langendoen, EJ, Shields Jr. FD (eds.) Proceedings of Conference on Management of Landscapes Disturbed by Channel Incision, 20-22 May 1997, Univ. of Miss, Oxford, MS, pp 1093-1099

Davidson DW, Kapustka LA, Koch RG (1989) The role of plant root distribution and strength in moderating erosion of red clay in the Lake Superior watershed. Trans Wis Acad Sci Arts Lett 77:51-63

De Baets S, Poesen J (2010) Empirical models for predicting the erosion-reducing effects of plant roots during concentrated flow erosion. Geomorphology 118:425-432

De Baets S, Poesen J, Knapen A, Barberá GG, Navarro JA (2007) Root characteristics of representative Mediterranean plant species and their erosion-reducing potential during concentrated runoff. Plant Soil 294:169-183

Descroix L, Viramontes D, Vauclin M, Gonzalez Barrios JL, Esteves M (2001) Influence of soil surface features and vegetation on runoff and erosion in the Western Sierra Madre (Durango, Northwest Mexico). Catena 43:115-135

Descroix L, Barrios JLG, Viramontes D, Poulenard J, Anaya E, Esteves M, Estrada J (2008) Gully and sheet erosion on subtropical mountain slopes: their respective roles and the scale effect. Catena 72:325-339

Fekedulegn BD, Colbert JJ, Hicks RR Jr., Schuckers, ME (2002) Coping with multicollinearity: an example on application of principal components regression in dendroecology. U.S. Department of Agriculture, Forest Service, Northeastern Research Station, Newton Square, PA

Flanagan DC, Nearing MA (1995) USDA-water erosion prediction project, hillslope profile and watershed model documentation. National soil erosion research laboratory report 10 .
USDA-ARS National Soil Erosion Research Laboratory, West Lafayette, IN

Ghidey F, Alberts EE (1997) Plant root effects on soil erodibility, splash detachment, soil strength, and aggregate stability. Trans Am Soc Agric Eng 40:129-135

Gray DH (1978) Role of woody vegetation in reinforcing soils and stabilizing slopes. In: Proceedings of symposium on soil reinforcing and stabilizing techniques in engineering practice. NSW Institute of Technology, Sydney, pp 253-306

Gyssels G, Poesen J (2003) The importance of plant root characteristics in controlling concentrated flow erosion rates. Earth Surf Process Landf 28:371-384

Gyssels G, Poesen J, Bochet E, Li Y (2005) Impact of plant roots on the resisitence of soils to erosion by water: a review. Prog Phys Geogr 29:1-28

Hall RL, Calder IR (1993) Drop size modification by forest canopies: measurements using a disdrometer. J Geophys Res 98:18465-18470

Hughes AO, Olley JM, Croke JC, McKergow LA (2009) Sediment source changes over the last 250 years in a dry-tropical catchment, central Queensland, Australia. Geomorphology 104: 262-275

Kirkby MJ, Bracken LJ (2009) Gully processes and gully dynamics. Earth Surf Process Landf 34:1841-1851

Li Y (1995) Plant roots and soil resistance to erosion on the Loess Plateau. Science Press, Beijing

Li Y, Zhu XM, Tian JY (1991) Effectiveness of plant roots to increase the anti-scourability of soil on the Loess Plateau. Chin Sci Bull 36:2077-2082

Li Y, Xu XQ, Zhu XM (1992) Preliminary study on mechanism of plant roots to increase soil anti-scouribility on the Loess Plateau. Sci China (Series B) 35:1085-1092

Li Y, Poesen J, Yang JC, Fud B, Zhang JH (2003) Evaluating gully erosion using ${ }^{137} \mathrm{Cs}$ and ${ }^{210} \mathrm{~Pb} /{ }^{137} \mathrm{Cs}$ ratio in a reservoir catchment. Soil Tillage Res 69:107-115

Li Y, Poesen J, Valentin C (2004) Gully erosion under global change. Sichuan Science Technology Press, Chengdu

Li Y, Zhang QW, Wan GJ, Huang RG, Piao HC, Bai LY, Li L (2006) Physical mechanisms of plant roots affecting weathering and leaching of loess soil. Earth Sci 49:10021008

Liu DH (2006) Impacts of Eulaliopsis Binata hedgerow system on soil and water losses in Purple Hilly Area, SW-China. Chinese Academy of Agricultural Sciences, Beijing

Lutes DC (2002) Assessment of the line transect method: an examination of the spatial patterns of down and standing dead wood. USDA Forest Service Gen. Tech. Rep. PSWGTR-181, Washington, D.C

Mohammad AG, Mohammad AA (2010) The impact of vegetative cover type on runoff and soil erosion under different land uses. Catena 81:97-103

Moreno-de las Heras M, Merino-Martin L, Nicolau JM (2009) Effect of vegetation cover on the hydrology of reclaimed mining soils under Mediterranean-Continental climate. Catena 77:39-47

Nunes AN, de Almeida AC, Coelho COA (2011) Impacts of land use and cover type on runoff and soil erosion in a marginal area of Portugal. Appl Geogr 31:687-699

Piao SL, Fang JY, Ciais P, Peylin P, Huang Y, Sitch S, Wang T (2009) The carbon balance of terrestrial ecosystems in China. Nature 458:1009-1013 
Poesen J, Vandaele K, van Wesemael B (1998) Gully erosion: importance and model implications. In: Boardman J, FavisMortlock D (eds) Modelling soil erosion by water. Springer, London, pp 285-311

Poesen J, Vanwalleghem T, de Vente J, Knapen A, Verstraeten G, Martinez-Casasnovas JA (2006) Gully erosion. In: Boardman J, Poesen J (eds) Soil erosion in Europe. Wiley, Chichester, pp 515-536

Rebeca VM, Eusebio VR, Klaudia O, Luis HS, Parrot JF, Mark AN (2010) Soil erosion and runoff in different vegetation patches from semiarid Central Mexico. Catena 80:162-169

Renard KG, Foster GR, Weesies GA, McCool DK, Yoder DC (1997) Predicting soil erosion by water: a guide to conservation planning with the Revised Universal Soil Loss Equation (RUSLE). Agriculture Handbook 703. US Department of Agriculture-Agricultural Research Service, Washington, DC

Simon A, Collison A (2002) Quantifying the mechanical and hydrologic effects of riparian vegetation on streambank stability. Earth Surf Process Landf 27:527-546

Singer MJ, Bissonnais YL (1998) Importance of surface sealing in the erosion of some soils from a Mediterranean climate. Geomorphology 24:79-85

Snyman HA, duPreez CC (2005) Rangeland degradation in semiarid South Africa-II: influence on soil quality. J Arid Environ 60:483-507

Sorriso-Valvo M, Bryan RB, Yair A, Iovino F, Antronico L (1995) Impact of afforestation on hydrological response and sediment production in a small Calabrian catchment. Catena 25:89-104
Styczen ME, Morgan RPC (1995) Engineering properties of vegetation. In: Morgan RPC, Rickson RJ (eds) Slope stabilization and erosion control: a bioengineering approach. E \& F.N. Spon, London, pp 5-58

Tengbeh GT (1993) The effect of grass roots on shear strength variations with moisture content. Soil Technol 6:287-295

Valentin C, Poesen J, Li Y (2005) Gully erosion: impacts, factors and control. Catena 63:132-153

Vandekerckhove L, Poesen J, Oostwoud Wijdenes D, Nachtergaele J, Kosmas C, Roxo MJ, De Figueiredo T (2000) Thresholds for gully initiation and sedimentation in Mediterranean Europe. Earth Surf Process Landf 25:12011220

Walling DE, He Q (1997) Use of fallout ${ }^{137} \mathrm{Cs}$ in investigations of overbank sediment deposition on river floodplains. Catena 29:263-282

Wynn TM, Mostaghimi S (2006) The effects of vegetation and soil type on streambank erosion, southwestern Virginia, USA. J Am Water Resour Assoc 42:69-82

Wynn T, Mostaghimi S, Burger J, Harpold A, Henderson M, Henry LA (2004) Variation in root density along stream banks. J Environ Qual 33:2030-2039

Yang SL, Zhao QY, Belkin IM (2002) Temporal variation in the sediment load of the Yangtze River and the influences of human activities. J Hydrol 263:56-71

Zhao QG (2006) Some considerations for present soil and water conservation and ecology security of south China. Bull Soil Water Conserv 26:1-8 